\title{
EFFECT OF PHYTIC ACID FROM RICE AND CORN ON MORPHOLOGY, CELL PROLIFERATION, APOPTOSIS AND CYCLOOXYGENASE-2 EXPRESSION IN SWINE JEJUNAL EXPLANTS
}

\author{
Efeito do ácido fítico de arroz e milho sobre a morfologia, proliferação celular, \\ apoptose e expressão da ciclo-oxigenase- 2 em explantes jejunais de suínos
}

\author{
Elisângela Olegário da Silva ${ }^{1}$, Juliana Rubira Gerez ${ }^{1}$, Ana Paula Frederico Rodrigues Loureiro Bracarense ${ }^{2}$
}

\begin{abstract}
Phytic acid (IP6) is a potent antioxidant present in several natural foods. Beneficial effects on colon cancer and inflammation have been associated to IP6 in several studies, however, scarce data about the effect on small intestine are available. The aim of the present study was to evaluate the effect of different doses of IP6 from rice and corn on intestinal morphology, cellular proliferation, apoptosis and cyclooxygenase-2 (Cox-2) expression using swine jejunal explants as experimental model. This report demonstrated that explants treated with $0.5 \mathrm{mM}, 2.5 \mathrm{mM}$ and $5 \mathrm{mM}$ of IP6 from rice and $2.5 \mathrm{mM}$ and $5 \mathrm{mM}$ from corn showed higher villi height compared to control. Explants treated with $2.5 \mathrm{mM}$ and $5 \mathrm{mM}$ IP6 from rice exhibited a significant reduction on intestinal histological changes (villi atrophy and fusion, edema, lymphatic vessel dilation, loss of apical enterocytes, cell vacuolation, necrotic debris, morphology of enterocytes and microvilli and number of villi). The cellular proliferation decreased in the explants treated with the dosages of $2.5 \mathrm{mM}$ and $5 \mathrm{mM}$ from rice and a significant decrease in cell apoptosis was observed in the treatments with $2.5 \mathrm{mM}$ IP6 from rice and $5 \mathrm{mM}$ IP6 from corn compared to the control. The explants treated with $2.5 \mathrm{mM}$ and $5 \mathrm{mM}$ IP6 from rice and corn showed a significant reduction of the Cox-2 expression. Higher dosages of IP6 from rice and corn used in this experiment increased the viability and preservation of intestinal tissue as evidenced by morphological and immunohistochemical assays.
\end{abstract}

Index terms: IP6, natural antioxidant, jejunum, swine, explants technique

\section{RESUMO}

O ácido fítico (IP6) é um potente antioxidante presente em diversos alimentos naturais. Estudos demonstram os efeitos benéficos do IP6 sobre câncer e inflamação de cólon, no entanto, dados sobre a ação do IP6 no intestino delgado são escassos. O objetivo do presente estudo foi avaliar os efeitos em diferentes doses de IP6 extraídos de arroz e de milho sobre a morfologia do intestino, proliferação celular, apoptose e expressão de ciclo-oxigenase-2 (Cox-2) usando explantes jejunais de suínos como modelo experimental. Este estudo demonstrou que explantes tratados com $0,5 \mathrm{mM}, 2,5 \mathrm{mM}$ e $5 \mathrm{mM}$ de IP6 de arroz e $2,5 \mathrm{mM}$ e $5 \mathrm{mM}$ de milho mostraram maior altura de vilosidades quando comparados ao controle. Os explantes tratados com 2,5 mM e $5 \mathrm{mM}$ de IP6 de arroz apresentaram uma redução significativa nas alterações histológicas intestinais (atrofia e fusão de vilosidades, edema, dilatação de vasos linfáticos, perda apical de enterócitos, vacuolização celular, debris necróticos, morfologia de enterócitos, microvilosidades e número de vilosidades). A proliferação celular diminuiu nos explantes tratados com as doses de 2,5 e $5 \mathrm{mM}$ de arroz e observou-se uma redução na apoptose nos tratamentos com 2,5 mM de IP6 de arroz e $5 \mathrm{mM}$ de milho comparados aos explantes controles. Os explantes tratados com 2,5 mM e 5 mM de IP6 de arroz e milho mostraram uma redução significativa na expressão de Cox-2. Os exames morfológicos e imuno-histoquímicos evidenciaram que as maiores doses de IP6 de arroz e milho aumentaram a viabilidade e preservação do tecido intestinal.

Termos para indexação: IP6, antioxidante natural, jejuno, suíno, técnica de explantes

\section{INTRODUCTION}

Phytic acid (IP6) is a natural antioxidant present in cereals, legumes, nuts, oil seeds, spores, needles and pollen, compounding approximately $1-5 \%$ of weight and, accounting for $60-90 \%$ of the total seed phosphorus (Lolas, Palamidis; Markakis; 1976; Graf; Eaton 1990). In rice and corn, cereals widely consumed by humans and animals, the IP6 is concentrated mainly in the pericarp and in the germ, representing $2.2 \%$ and $6.4 \%$ of weight, respectively (Graf; Eaton, 1990).
During storage, fermentation, germination, and digestion of cereals, IP6 can be dephosphorylated in lower phosphoric esters of myo-inositol (IP5, IP4, IP3, IP2 and IP) by action of endogenous phytase or by acid hydrolysis and enzymatic treatment with phytase (Burbano et al. 1995). The IP4 and IP3 play an important role in cell signalling and calcium mobilization (Shamsuddin; Elsayed; Ullah; 1999). The IP6 and IP5 are present within the cells in substantial amounts $(10 \mu \mathrm{M}$ to $1 \mathrm{mM})$. These levels are much higher than any other inositol phosphates

\footnotetext{
${ }^{1}$ Universidade Estadual de Londrina/UEL - Londrina - Londrina - PR - Brasil

${ }^{2}$ Universidade Estadual de Londrina/UEL - Departamento de Medicina veterinária/DMVP - Rodovia Celso Garcia Cid - Pr 445 Km 380 - Campus Universitário - Cx. P. 10.011 - 86.057-970 - Londrina - PR - Brasil - ana.bracarense@pq.cnpq.br

Received in December 24, 2013 and approved in March 18, 2014
}

Ciênc. Agrotec., Lavras, v.38, n. 3, p.278-285, maio./jun., 2014 
(Szwergold; Grahma; Brown 1987), inducing a high capacity to bind minerals (Sandberg; Carlsson; Svanberg 1989).

The effects of IP6 have been demonstrated in different pathological conditions as inhibition of platelet aggregation (Vucenik; Podeczasy; Shamsuddin; 1999), reduction of serum lipids (Onomi; Okazaki; Katayama; 2004), prevention of cardiovascular diseases (Grases et al. 2006), kidney stone formation (Grases et al. 1996) and inflammatory bowel diseases (Graf; Eaton, 1985), as well as a protective effect in neurodegenerative diseases (Xu; Kanthasamy; Reddy 2008; Anekonda et al. 2011). Moreover, several studies in vitro (Tantivejkul; Vucenik; Shamsuddin; 2003; Gu et al. 2009, Kapral et al. 2012) and in vivo using animal models (Shamsuddin, Elsayed; Ullah; 1999; Challa, Rao; Reddy 1997; Lee; Lee; Choi 2005; Khatiwada et al. 2011) described a decrease in the development of several cancers. The antineoplasic effect is a consequence of increased apoptosis, and decreased tumor cell proliferation, metastasis, and preneoplastic lesions. Some clinical studies suggested that IP6 potentiated the action of chemotherapeutic drug and minimized symptoms in people with breast and colon cancer (Druzijanic et al. 2004, Bacic et al. 2010).

The hypothesis for IP6 antioxidant and anticarcinogenic action is inhibition of reactive oxygen species (ROS) generation as a result of a strong chelation with iron (Graf; Eaton, 1985). The mechanisms of degradation and hydrolysis of IP6 in the gastrointestinal system have been elucidated (Schlemmer et al. 2001), however, no data about the effect of IP6 on small intestine morphology are available. The interactions and pathways modulated by IP6 from different origins and a possible beneficial result in the gastrointestinal tract remain unknown.

We used the swine as experimental model based on physiological and morphological similarities with the human gastrointestinal tract, as well as in the absorption of IP6 (Schlemmer et al. 2001). The explant culture technique used in this experiment permits to evaluate tissue morphology, maintaining the complex patterns of differentiation seen in vivo (Randall; Turton; Foster; 2011). In this study, we investigated the effects of IP6 from rice and corn in different doses on intestinal morphology, cellular proliferation, apoptosis and Cox-2 expression using swine jejunal explants.

\section{MATERIAL AND METHODS}

\section{Animals}

Six 24-days-old crossbred (Landrace $x$ Large White $\mathrm{X}$ Duroc) piglets $(7.2 \mathrm{~kg} \pm 0.63)$ were used in the present study. All animal experimentation procedures were carried out in accordance with the Ethics Committee on the use of animals (CEUA/UEL/Brazil-process n ${ }^{\circ}$ 8022.2012.40).

\section{Phytic acid}

The phytic acid dodecasodium salt from rice (MW: 1080) and corn (MW: 1044) were purchased from Sigma -Aldrich (St. Louis, MO). The salts were dissolved in distillate water, the $\mathrm{pH}$ adjusted to 7.2 and the solution stored at $-20^{\circ} \mathrm{C}$. The range of IP6 concentration used in this study $(0.5 \mathrm{mM}, 1.0 \mathrm{mM}, 2.5 \mathrm{mM}$ and $5.0 \mathrm{mM})$ was chosen to encompass levels previously used with IPEC-1 (Intestinal Porcine Epithelial Cells) cell line (Pacheco et al. 2012).

\section{Jejunal explants technique}

The piglets were euthanized by administration of acepromazine $1 \%(0.1 \mathrm{~mL} / 10 \mathrm{Kg})$ intramuscular, sodium pentobarbital $(40 \mathrm{mg} / \mathrm{Kg})$ intravenous and subsequently $\mathrm{KCl} 15 \%$ solution intravenous. The jejunum was rapidly excised, and fragments of $5 \mathrm{~cm}$ length were collected and washed with buffer solution. The explants were collected using a punch of $8 \mathrm{~mm}$ diameter. From each animal six explants were collected for each treatment. The total number of explants from each pig was 54 . The explants collected were laid in six well plates (three explants/well) with $3 \mathrm{~mL}$ of the following treatments: control - only culture media (DMEM- Dulbecco's modified Eagle's medium, Gibco- BRL Life Technologies, Carlsbad, CA) plus penicillin/streptomycin $(1.25 \mu \mathrm{L} / \mathrm{mL}$, Gibco- BRL Life Technologies, Carlsbad, CA), gentamicin $(10 \mu \mathrm{L} / \mathrm{mL}$, Novafarma, Goiás, Brazil), fetal bovine serum $(100 \mu \mathrm{L} /$ $\mathrm{mL}$, Invitrogen, São Paulo, Brazil) and L-glutamine (0.4 $\mu \mathrm{L} / \mathrm{mL}$, Sigma-Aldrich, St. Louis, MO); culture media with IP6 from corn $(0.5 \mathrm{mM}, 1.0 \mathrm{mM}, 2.5 \mathrm{mM}, 5.0 \mathrm{mM})$ and culture media with IP6 from rice $(0.5 \mathrm{mM}, 1.0 \mathrm{mM}$, $2.5 \mathrm{mM}, 5.0 \mathrm{mM})$. The explants were incubated during four hours at $37^{\circ} \mathrm{C}$ under orbital shaking and $5 \%$ of $\mathrm{CO}_{2}$. All the experimental procedures were performed in duplicated.

\section{Histological assessment}

After the incubation period, the explants were fixed in $10 \%$ neutral buffered formalin solution and routinely processed for histopathological and immunohistochemical evaluation. An intestinal histological score previously described (Bracarense et al. 2012) was adapted to compare histological changes between the treatments. The maximum score ( 22 points) indicates the overall integrity of the intestine. Each explant was evaluated to observe the presence and intensity of the criteria disposed on table 1 . 
Table 1 - Histological criteria score used to establish the jejunal lesional score*

\begin{tabular}{lcc}
\hline Type of lesion & $\begin{array}{c}\text { Severity } \\
\text { score }\end{array}$ & $\begin{array}{c}\text { Maximal total } \\
\text { score }\end{array}$ \\
\hline Villi atrophy & $0-2$ & 22 \\
Villi fusion & $0-2$ & \\
Interstitial edema & $0-2$ & \\
Lymphatic vessel dilation & $0-2$ & \\
Loss of apical enterocytes & $0-2$ & \\
Cell vacuolation & $0-2$ & \\
Necrotic debris & $0-2$ \\
Microvilli homogeneity & $0-2$ \\
Enterocytes morphology & $0-3$ \\
Number of villi & $0-3$ & \\
\hline
\end{tabular}

* The jejunal score of each treatment was obtained by the sum of each lesion score. The severity score was determined as: 0-diffuse; 1-local; 2-absent; \# Columnar epithelium (3); cuboid epithelium (2); flattened epithelium (1); no epithelium (0).

- $>25$ villi/explant (3); $15-25$ villi (2); $<15$ villi (1) and no villi (0).

The total score was calculated by taking into account the sum of each histological criteria. The villi height was measured randomly on 10 villi using the Motic Image Plus 2.0 software (Motic Instruments, Richmond, Canada). Sections of jejunum were submitted to Alcian blue staining to evaluate goblet cell density. Positively stained goblet cells were counted randomly in 10 villi per explant at 400x magnification.

\section{Immunohistochemical assessment}

Evaluation of cell proliferation, apoptosis and Cox- 2 expression were performed using antibodies against Ki-67 (clone 7B11, 1:50 dilution, Zymed, Carlsbad, CA) and cleaved caspase-3 (CCasp3) (clone Asp 175, 1:200 dilution, Cell Signalling Technology, Beverly, MA) and Cox-2 (clone CX-294, 1:100 dilution, Dako, Glostrup, Denmark), respectively. The protocols, positive and negative controls were used according to manufacturer's instructions. The immunoexpression of Ccasp 3 and Ki-67 was estimated by counting strongly positive immunostaining of cytoplasm and nucleus cells, respectively, in five random fields in crypt region /explant at 400X magnification. The expression of Cox-2 was estimated by evaluation of positive immunostaining of cytoplasm cells in five fields in crypt region/explant at 200x magnification. Fields were considered positive when it showed $75 \%$ or more positive immunostaining cells.

\section{Statistical analysis}

The experimental design used in the present study was entirely randomized with six replicates (each explant represent one replicate). The means of lesional score, intestinal morphometry, number of goblet cells and positive immunostaining for Ki-67 and Ccasp3 and the sum of the positive and negative immunostaining fields for Cox-2 were used for statistical analysis. Data were statistically analyzed by the free software R 2.11.1 using normality (Shapiro-Wilk's test) and homogeneity (Bartlett) tests. When these two assumptions were met, the analysis of variance (ANOVA) was applied, followed by Tukey's test and presented with their standard errors to Ki-67, CCasp-3. The data of Cox-2 expression were exhibited in percentage of positive and negative immunostaining. The $P$ values of $\leq 0.05$ were considered significant.

\section{RESULTS AND DISCUSSION}

After 4 hours of incubation, untreated explants presented mild to moderate multifocal atrophy and villi fusion. On the other hand, explants exposed to IP6 showed normal villi height and morphology (Figure 1A, 1B). The control explants showed a mean histological score of 16.74. A significant increase in the histological score was observed in explants treated with $2.5 \mathrm{mM}$ $($ score $=19.00 ; \mathrm{P}=0.006)$ and $5.0 \mathrm{mM}($ score $=19.35$; $\mathrm{P}=0.001)$ of rice IP6, whereas the doses of $0.5 \mathrm{mM}$ $($ score $=17.56)$ and $1.0 \mathrm{mM}($ score $=17.56)$ induced no difference compared to control explants. No significant difference was observed in explants treated with corn IP6 in all experimental doses when compared with untreated explants $(0.5 \mathrm{mM}$ score $=17.78 ; 1.0 \mathrm{mM}$ score $=17.48$; $2.5 \mathrm{mM}$ score $=18.06$ and $5.0 \mathrm{mM}$ score $=17.51)$. The $\mathrm{P}$ value was $>0.05$ (Figure 1C).

Explants exposed to IP6 exhibited higher villi height compared to control (villi height $=263.02$ ). This difference was significant for explants exposed to IP6 from rice in the concentrations of $0.5 \mathrm{mM}$ (villi height $=307.89$, increased $17 \% ; \mathrm{P}=0.043$ ), $2.5 \mathrm{mM}$ (villi height $=308.71$, increased $17 \% ; \mathrm{P}=0.038$ ) and $5 \mathrm{mM}$ (villi height $=329.31$, increased $23 \% ; \mathrm{P}=0.01$ ), and $2.5 \mathrm{mM}$ (villi height $=314.05$, increased $19 \% ; \mathrm{P}=0.011$ ) and $5 \mathrm{mM}$ (villi height $=321.06$, increased $20 \% ; \mathrm{P}=0.003$ ) of corn IP6 as observed in the Figure 1D. The mean of goblet cells per villi was 4.1 for control explants. Explants incubated with rice and corn IP6 showed a non-significant increase in the number of goblet cells in all treatments $(\mathrm{P}>0.05)$. 


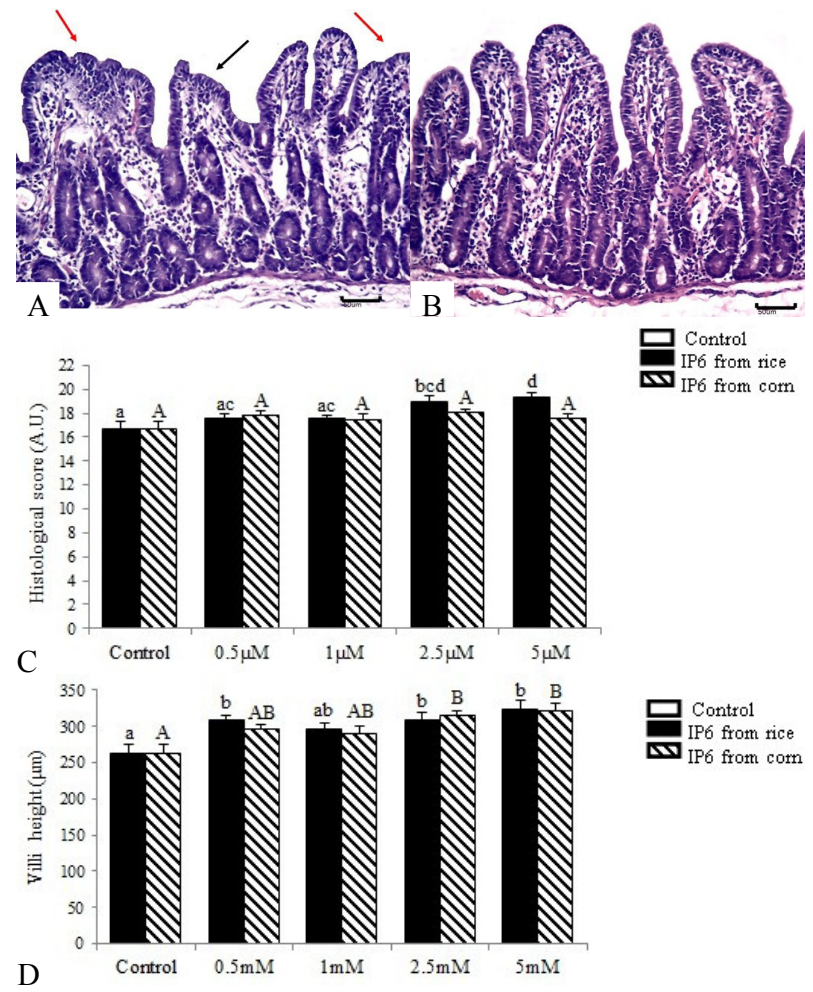

Figure 1 - Effect of IP6 from rice and corn on jejunum explants histology. A-Control with moderate lesions, villi atrophy (black arrow) and villi fusion (red arrows), , H\&E, bar $50 \mu \mathrm{m}$. B- Jejunal explant incubated with $5 \mathrm{mM}$ IP6 from rice showed decrease of lesions compared to control, H\&E $50 \mu \mathrm{m}$. C-Histological score after examination according to the occurrence of lesions in explants submitted to IP6 from rice and corn . (AU-Arbitrary units). D- Villi height of explants submitted to IP6 from rice and corn. Values are mean height $(\mu \mathrm{m})$. Values are means with standard errors of the mean represented by vertical bars (n 6 animals). Mean values with unlike letters were significantly different $(\mathrm{P}<0.05)$.

Cell proliferation, apoptosis and Cox-2 expression were evaluated using an immunohistochemical assay. We have chosen explants exposed to $2.5 \mathrm{mM}$ and $5.0 \mathrm{mM}$ of IP6 considering that these treatments have improved intestinal morphology. A significant reduction in the number of positive Ki-67 cells was verified in explants incubated with $2.5 \mathrm{mM}$ (positive cells $=41.43$, decreased $32.8 \% ; \mathrm{P}=0.005$ ) and $5 \mathrm{mM}$ (positive cells $=43.72$, decreased $32.1 \% ; \mathrm{P}=0.001)$ of rice IP6 compared to control explants (positive cells $=55.15)($ Fig. 2A; Fig. $3 \mathrm{~A}, 3 \mathrm{~B}$ ). The explants treated with $2.5 \mathrm{mM}$ (positive cells $=49.63$ ) and $5.0 \mathrm{mM}$ (positive cells $=47.94$ ) of corn
IP6 showed no significant reduction of $10 \%$ and $13 \%$ respectively $(\mathrm{P}>0.05)$ compared to control explants (Figure 2A). A significant decrease in the number of apoptotic cells was observed in explants treated with 2.5 $\mathrm{mM}$ of rice IP6 (positive cells $=35.02$, decreased 25\%; $\mathrm{P}=0.003$ ) and $5 \mathrm{mM}$ of corn IP6 (positive cells $=37.23$, decreased $13 \% ; \mathrm{P}=0.05)$ when compared to control samples (positive cells= 52.14) (Figure 2B; figure 3C, D). The positive immunoexpression of Cox-2 in the explants treated with $2.5 \mathrm{mM}$ (positive fields $=34$, decreased $62 \%$, $\mathrm{P}=2.484 \mathrm{E}-10$ ) and $5.0 \mathrm{mM}$ (positive fields $=21$, decreased $76 \%, \mathrm{P}=8.063 \mathrm{E}-14$ ) from rice and $2.5 \mathrm{mM}$ (positive fields $=32$, decreased $64 \%, \mathrm{P}=6.451 \mathrm{E}-10)$ and $5.0 \mathrm{mM}$ (positive fields $=16$, decreased $82 \%, \mathrm{P}=4.691 \mathrm{E}-17$ ) from corn showed a significant reduction as compared with the control group (positive fields=90) (Figure 2C, D).

In the present study, we have investigated the effect of different doses of phytic acid from rice and corn on the intestine of piglets in order to determine if they have an effect on jejunal morphology, cell turnover and pro-inflammatory stimuli. The IP6 exerts its effects in a dose-dependent manner (Graf; Eaton, 1990) which can explain the response to greater doses of phytic acid. In an in vitro study, IPEC- 1 cells exposed to 0.5 and 1 $\mathrm{mM}$ of phytic acid protected cells from deoxynivalenol toxicity, whereas doses of $5 \mathrm{mM}$ induced cell toxicity (Pacheco et al. 2012). We have observed that explants exposed to $2.5 \mathrm{mM}$ and $5 \mathrm{mM}$ of phytic acid improved jejunal morphology and the IP6 from rice was more efficient to preserve the intestinal morphology compared to IP6 from corn. We hypothesize that the different number of sodium and water molecules present in the IP6 from rice $(\mathrm{C} 6 \mathrm{H} 6 \mathrm{O} 24 \mathrm{P} 6.12 \mathrm{Na} .8 \mathrm{H} 2 \mathrm{O})$ and from corn $(\mathrm{C} 6 \mathrm{H} 6 \mathrm{O} 24 \mathrm{P} 6.11 \mathrm{Na} .7 \mathrm{H} 2 \mathrm{O})$ could interfere with the absorption of IP6 by intestinal cells reflecting the difference in morphological preservation observed in this experiment.

This improvement could be seen by a decrease in villi fusion and atrophy, as well as normal enterocytes morphology. In this study, villi were significantly higher in explants exposed to concentrations of 2.5 and $5 \mathrm{mM}$ of both phytic acids. An increased villous surface implicates an augmentation in intestinal absorptive capacity (Wijtten; Van Der; Verstegen 2011). Goblet cells secrete a mucus layer that promotes the first line of defence on intestine (Kim; Ho 2010). We observed no difference in goblet cell density in explants submitted to different doses of phytic acid. Probably, the short period of incubation (four hours) was not sufficient for goblet cells migration from crypts to villi. 

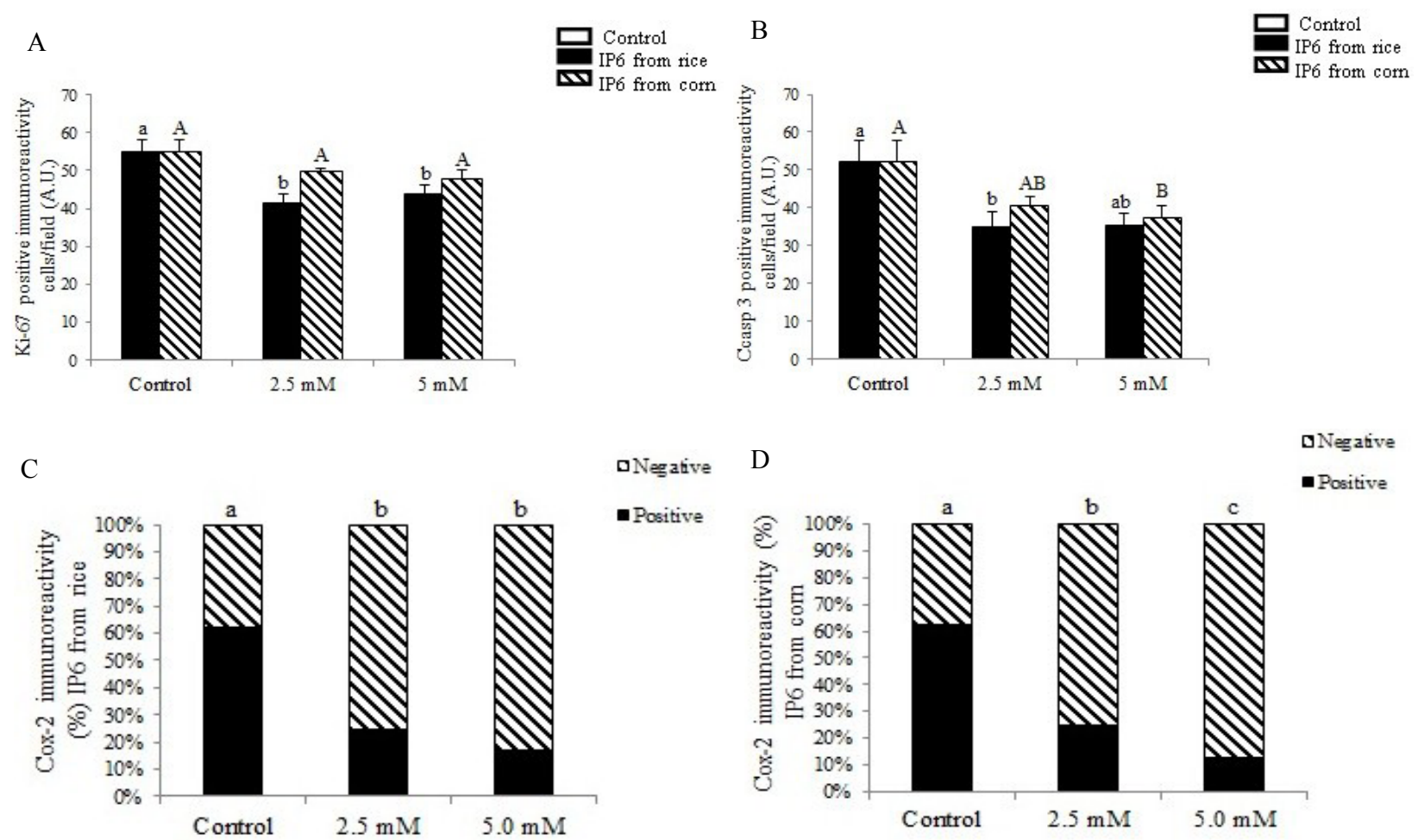

Figure 2 - Effect of IP6 from rice and corn on jejunum explants cellular proliferation, apoptosis and Cox-2 expression. Immunohistochemistry using the immunoperoxidase method and hematoxylin counterstain. APositive cell immunostaining for Ki-67 in explants submitted to $2.5 \mathrm{mM}$ and $5 \mathrm{mM}$ from rice and corn. Values are mean positive cells per field. B- Immunostaining for CCasp3 in explants submitted to $2.5 \mathrm{mM}$ and $5 \mathrm{mM}$ from rice and corn.Values are mean positive cells per field. Values are means with standard errors of the mean represented by vertical bars (n 6 animals). C- Immunostaining for Cox-2 in explants submitted to IP6 from rice. D. Immunostaining for Cox-2 in explants submitted to IP6 from rice. Values are expressed as percentage of positive and negative immunostaining fields represented by vertical bars (n 6 animals). Unlike letters were significantly different $(\mathrm{P}<0.05)$.

Time of incubation is a limitation in the explant model. In previous studies we have observed an increase in histological changes (30\%) in explants incubated for 4 hours compared to non-incubated explants (unpublished data). The explants are submitted to a relative status of hypoxia. Whenever oxygen level decrease in the surrounding environment, the mitochondria increase the levels of cytosolic reactive oxygen species (ROS) to activate hypoxia-inducible factor (HIF) with the objective to facilitate cellular adaptation to hypoxia (Bell et al. 2007). However, if the cell was submitted to persistent hypoxia as in the present study, these ROS may induce a shift in iron redox state from $\mathrm{Fe}^{2+}$ to $\mathrm{Fe}^{3+}$ (Fenton reaction), limiting an essential cofactor of the PHDs (prolyl hydroxylase enzymes), resulting in an inhibition of hydroxylation of HIF protein (Gerald et al. 2004).
Furthermore, ROS can activate the MAPKs (mitogen-activated protein kinases) that have been associated to cell proliferation, apoptosis and regulation of Cox-2 gene (Wang et al. 1998). Cox-2 is an enzyme involved in arachidonic acid metabolism and is not expressed in most of the normal tissues, but is strongly induced by mitogenic and proinflammatory stimuli. High levels of Cox-2 have been reported in inflammatory bowel disease and colon cancer (Cianchi et al. 2006). ). In this study, we observed that the IP6, mainly from rice, decreased the cell proliferation, apoptosis and Cox-2 expression due their antioxidant potential by inhibition of ROS production and capacity of modulate the signaling intracellular to preserve the tissue viability. 


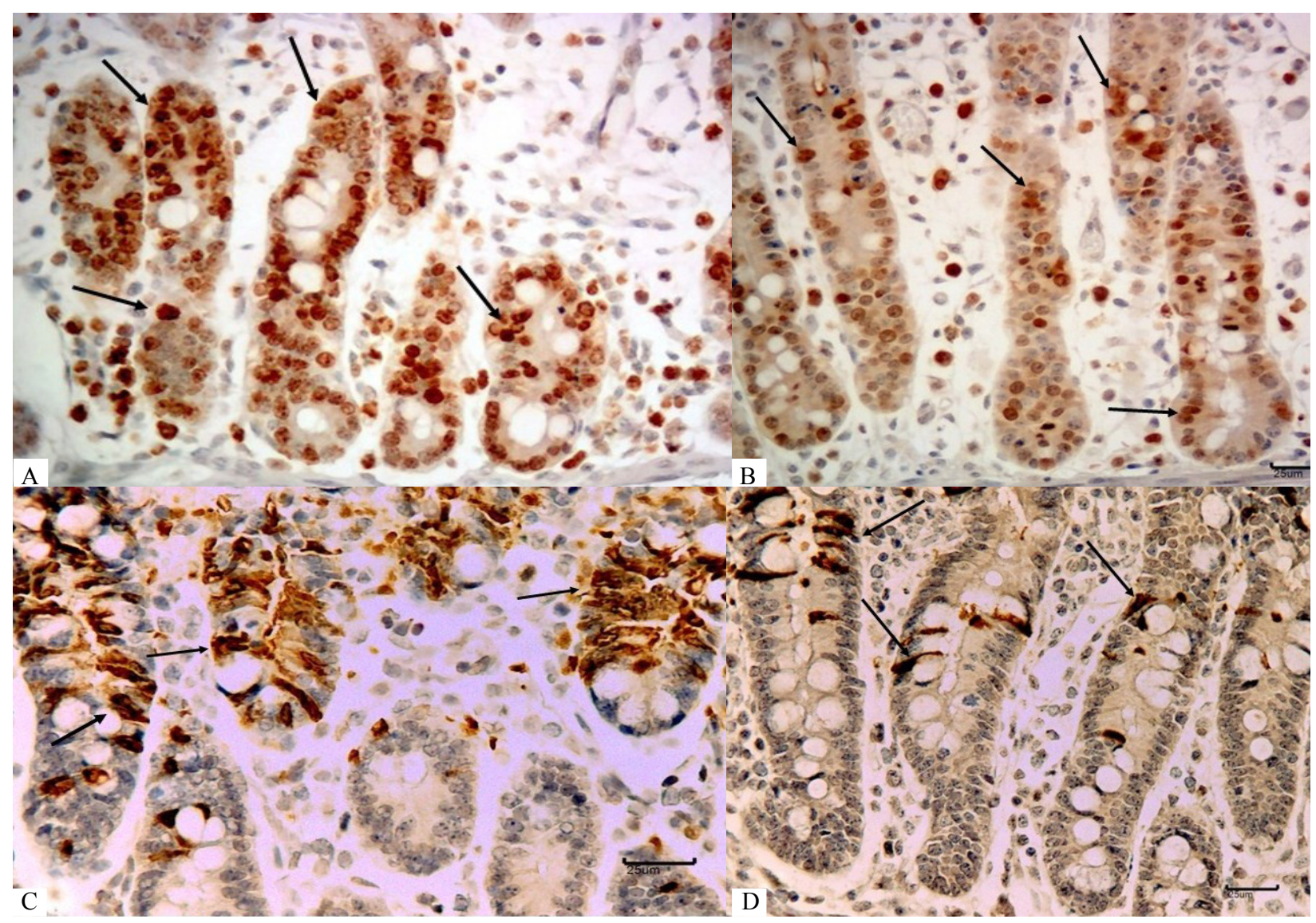

Figure 3 -Effect of IP6 on jejunum explants on cellular proliferation, apoptosis and Cox-2 expression. Nuclear immunohistochemical staining for Ki-67 and cytoplasmic immunohistochemical staining for CCasp3. A. Ki-67, Control, (nuclear staining, arrows), bar $25 \mu \mathrm{m}$. B. Ki-67, IP6 $5 \mathrm{mM}$ from rice, (nuclear staining, arrows), bar $25 \mu \mathrm{mCCasp}$ C- CCasp3, Control, bar $25 \mu \mathrm{m}$ (cytoplasmic staining, arrows). D. CCasp 3, IP6 $5 \mathrm{mM}$ from rice, bar $25 \mu \mathrm{m}$ (cytoplasmic staining, arrows).

IP6 can interfere with the Fenton reaction, stabilizing the iron in the $\mathrm{Fe}^{3+}$ (inert form) (Graf; Eaton, 1985), enabling a signalling for cellular adaptation to hypoxia, inhibiting the activation of MAPKs and preventing cellular injury, proliferation, apoptosis and Cox-2 expression by the inhibition of ROS production as observed in this experiment. The preservation of cellular morphology, increased villi height and decreased apoptosis and cell proliferation, promoted increased intestinal homeostasis and integrity, and in consequence better absorption of nutrients and defence against aggressors.

\section{CONCLUSIONS}

The IP6 from rice increased the viability and preservation of intestinal tissue by improvement on intestinal morphology, decrease of cellular proliferation, apoptosis and Cox-2 expression and the IP6 from corn increased the villi height and decreased the apoptosis and the Cox-2 expression. Nevertheless, more studies are necessary to elucidate biochemical pathways and molecular mechanisms of IP6 on the gastrointestinal tract and possible protective effects against infectious agents and xenobiotics.

\section{ACKNOWLEDGMENTS}

This study was supported by Grant n ${ }^{\circ} 305274 / 2011-$ 2 from CNPq, Brazil. E.O.S. and J.R.G. were supported by fellowships from CAPES. A.P.F.R.L.B. was supported by fellowship from CNPq. The authors wish to thank the Professor Dr. Caio Abércio da Silva for the supply and care of the animals and the Professor Dr. Elza Iouko Ida for helpful discussion about the antioxidant effect of phytic acid. 


\section{REFERENCES}

ANEKONDA, T,S. et al. Phytic acid as a potential treatment for Alzheimer's pathology: evidence from animal and in vitro models. Journal of Alzheimers Diseases. 23(1):21-35, 2011.

BACIC, I. et al. Efficacy of IP6+inositol in the treatment of breast cancer patients receiving chemotherapy: prospective, randomized, pilot clinical study. Journal of Experimental \& Clinical Cancer Research. 29(12):15, 2010 .

BELL, E.L. et al. The $\mathrm{Q}_{0}$ site of the mitochondrial complex III is required for the transduction of hypoxia signaling via reactive oxygen species production. The Journal of Cell Biology.177(6):1029-1036, 2007.

BRACARENSE, A-P.F.L. et al. Chronic ingestion of deoxynivalenol and fumonisin, alone or in interaction induces morphological and immunological changes in the intestine of piglets. British Journal of Nutrition. 107(2):1776-1786, 2012.

BURBANO, C. et al. Determination of phytate and lower inositol phosphates in Spanish legumes by HPLC methodology. Food Chemistry. 52(3):321-325, 1995.

CHALLA, A.; RAO, D.R.; REDDY, B. Interactive suppression of aberrant crypt foci induced by azoxymethene in rat colon by phytic acid and green tea. Carcinogenesis. 18(10):2023-2026, 1997.

CIANCHI, F. et al. Inhibition of 5-lipoxygenase by MK886 augments the anti-tumor activity of celecoxib in human colon cancer cells. Molecular Cancer Therapeutics, Philadelphia. 5(11):2716-2726, 2006.

DRUZIJANIC, N. et al. IP6 +inositol as adjuvant to chemotherapy of colon cancer: our clinical experience. Anticancer Research. 24:3475, 2004.

GERALD, D. et al. JunD reduces tumor angiogenesis by protecting cells from oxidative stress. Cell. 118(6):781-794, 2004.

GRAF, E.; EATON, J.W. Dietary suppression of colonic cancer. Fiber or phytate? Cancer. 56(4):717-718, 1985.

. Antioxidant functions of phytic acid.

Free Radical Biology \& Medicine. 8(1):61-69, 1990.
GRASES, F. et al. Study of the effects of different substances on the early stages of papillary stone formation. Nephron. 73(4):561-568, 1996.

Phytate (myo-inositol hexakisphophate) inhibits cardiovascular calcifications in rats. Frontier in Bioscience. 1(11):136-142, 2006.

GU, M. et al. Inositol hexaphosphate suppresses growth and induces apoptosis in prostate carcinoma cells in culture and nude mouse xenograft: PI3K-Akt pathway as potential target. Cancer Research. 69(24):1-17, 2009.

KAPRAL, M. et al. The effect of inositol hexaphosphate on the expression of selected metalloproteinases and their tissue inhibitors in IL-1 $\beta$-simulated colon cancer cells. International Journal of Colorectal Disease. 27(11):1419-1428, 2012.

KHATIWADA, J. et al. Green tea, phytic acid, and inositol in combination reduced the incidence of azoxymethaneinduced colon tumor in fisher 344 male rats. Journal of Medicinal Food. 14(11):1313-1320, 2011.

KIM, Y.S.; HO, S.B. Intestinal goblet cells and mucins in health and disease: recent insights and progress.

Current Gastroenterology Reports. 12(5):319-330, 2010.

LEE, H.J.; LEE, S.A.; CHOI, H. Dietary administration of inositol and/or inositol-6-phophate prevents chemically-induced rat hepatocarcinogenesis. Asian Pacific Journal of Cancer Prevention. 6(1):41-47, 2005.

LOLAS, G.M.; PALAMIDIS, N.; MARKAKIS, P. The phytic acid-total phosphorus relation in barley, oats, soybeans and wheat. Cereal Chemistry Journal. 53(6):867- 871, 1976.

PACHECO, G.D. et al. Phytic acid protects porcine intestinal epithelial cells from deoxynivalenol (DON) cytotoxicity. Experimental and Toxicologic Pathology. 64(4):345-347, 2012.

ONOMI, S.; OKAZAKI, Y.; KATAYAMA, T. Effect of dietary level of phytic acid on hepatic and serum lipid status in rats fed a high-sucrose diet. Bioscience, Biotechnology and Biochemistry.68(6):1379-1381, 2004. 
RANDALL, K.J.; TURTON, J.; FOSTER, J.R. Explant culture of gastrointestinal tissue: a review of methods and applications. Cell Biology and Toxicology. 27(4):267-284, 2011.

SANDBERG, A-B.; CARLSSON, N.G.; SVANBERG, U. Effects of inositol tri-, tetra-, penta-, and hexaphosphates on in vitro estimation of iron availability. Journal of Food Science. 54(1):159-161, 1989.

SCHLEMMER, U. et al. Degradation of phytate in the gut of pigs-pathway of gastro-intestinal inositol phosphate hydrolysis and enzymes involved. Archives of Animal Nutrition. 55(4):255-280, 2001.

SHAMSUDDIN, A.M.; ELSAYED, A.M.; ULLAH, A. Suppression of large intestinal cancer in F344 rats by inositol hexaphosphate. Carcinogenesis. 9(4):577-580, 1999.

SZWERGOLD, B.S.; GRAHMA, R.A.; BROWN, T.R. Observation of inositol pentakis- and hexakis-phosphates in mammalian tissues by PNMR. Biochemical and Biophysical Research Communications. 149(3):874-881, 1987.
TANTIVEJKUL, K.; VUCENIK, I.; SHAMSUDDIN, A.M. Inositol hexaphosphate (IP6) inhibits key events of cancer metastasis: I. In vitro studies of adhesion, migration and invasion of MDA-MB 231 human breast cancer cells. Anticancer Research.23(5A):671-3679, 2003.

VUCENIK, I.; PODECZASY, J.J.; SHAMSUDDIN, A.M. Antiplatelet activity of inositol hexaposphate (IP6). Anticancer Research. 19(5A):3689-3693, 1999.

WIJTTEN, P.J.; VAN DER, M.; VERSTEGEN, M.W. Intestinal barrier function and absorption in pigs after weaning: a review. British Journal of Nutrition. 19(5A):967-981, 2011.

WANG, X. et al. The cellular response to oxidative stress: influences of mitogen- activated protein kinase signalling pathways on cell survival. Biochemical Journal. 333(2):291-300, 1998.

XU, Q.; KANTHASAMY, A.G.; REDDY, M.B. Neuroprotective effect of the natural iron chelator, phytic acid in a cell culture model of Parkinson's disease. Toxicology. 245(1-2):101-108, 2008. 